\title{
Contractual Allocation of Decision Rights and Incentives: The Case of Automobile Distribution
}

\author{
Benito Arruñada \\ Universitat Pompeu Fabra \\ Luis Garicano \\ University of Chicago \\ Luis Vázquez \\ Universidad de Salamanca
}

October 2, 1999

\begin{abstract}
We analyze empirically the allocation of rights and monetary incentives in automobile franchise contracts. These contracts substantially restrict the decision rights of dealers and grant manufacturers extensive contractual completion and enforcement powers, converting the manufacturers, de facto, in a sort of quasi-judiciary instance. Variation in the allocation of decision rights and incentive intensity is explained by the incidence of moral hazard in the relation. In particular, when the cost of dealer moral hazard is higher and the risk of manufacturer opportunism is lower, manufacturers enjoy more discretion in determining the performance required from their dealers and in using mechanisms such as monitoring, termination and monetary incentives to ensure such performance is provided. We also explore the existence of interdependencies between the different elements of the system. and find some complementarities between completion and termination rights, and between monitoring rights and the intensity of incentives.
\end{abstract}

JEL codes: L14, L22, L81, K12

\footnotetext{
* We thank Oliver Williamson for his advice and support and Jürgen Backhaus, Judith Chevalier, Harold Demsetz, Antony Dnes, Alberto Fernández, Manuel González, Tom Hubbard, Emilio Huerta, Peter Klein, Claude Ménard, Inés Macho, Cándido Paz-Ares, two anonymous referees and numerous workshop participants for their comments and suggestions. This work has benefited from financial support by DGESIC through grant PB95-0989.
} 


\section{INTRODUCTION}

This paper analyzes empirically the solutions provided by automobile franchising contracts to the moral hazard problems present in franchising relations. It goes further than the previous literature in that, rather than focusing only on the strictly "monetary" aspects of the contracts, or only on the assignment of a particular right, it analyzes the entire system of allocation of rights over substantive decisions and the monitoring, punishment and reward mechanisms. The paper finds that the discretionary power of manufacturers varies between different networks in a manner consistent with the differential impact of moral hazard. Contracts allow more discretion to manufacturers when the potential cost of dealer moral hazard is higher and when manufacturers' opportunism is better controlled by their reputation.

Most of the empirical literature on contract design has focused on the strictly "monetary" aspects of the contracts, whether dealing with compensation and incentives in firms (see Prendergast, 1999 for a survey of this literature) or, in franchising, with royalty rates and franchise fees (e.g. Lafontaine, 1992; Sen, 1993; Lafontaine and Shaw, 1996) ${ }^{1}$. A small but growing body of literature has studied the use of other contractual terms. The pioneering study here is Masten and Crocker's (1985) analysis of the use of take or pay provisions for natural gas as an incentive mechanism. In a work more related to ours, Gompers and Lerner (1996) systematically study the use of covenants in venture partnership agreements, and explain the variation partly as a consequence of the difference in the incidence of opportunistic behavior. Kaplan and Stronberg (1999) are closest to our work in that they study the whole system of rights allocation in venture capital contracts. In the franchising context, Dnes (1993), Mathewson and Winter

\footnotetext{
${ }^{1}$ Rather than on the contract terms, the bulk of the empirical literature on franchising focuses on the choice between franchising and vertical integration. See Lafontaine and Slade (1998) for an excellent survey of this literature.
} 
(1994) and Brickley (1998) have studied the use of some specific clauses and the extent to which complementarities between them exist. However, neither the general contractual design literature nor the franchising one have, to our knowledge, attempted to analyze empirically the role of each element in the system of contract terms and monetary incentives to the solution of the conflicts present in these relations, and the interactions between the different elements of the system.

In analyzing the allocation of decision rights by these contracts, we argue that assigning decision rights to one of the parties involves a trade-off between the risk of ex post opportunism on the two sides. More manufacturer discretion reduces the risk of moral hazard on the dealer side, while simultaneously intensifying the risk of manufacturer incentive and hold-up hazards. Thus we expect manufacturer discretion to increase with the importance of vertical and horizontal externalities and with manufacturer reputational capital.

We make three main sets of findings. First, we find that all contracts substantially limit the ex ante decision rights of franchisees, while granting extensive implementation, monitoring and enforcement powers to manufacturers. In particular, dealers must attain sales targets set by manufacturers, provide information and publicity as required by manufacturers, and use the quantity and quality of facilities, labor and machinery that manufacturers determine. Manufacturers also have a range of enforcement rights (monitoring, termination and use of monetary incentives) to ensure that these outcomes take place. We find substantial cross-brand variation on the contractual allocation of enforcement rights to manufacturers and some, but less important, variation in the allocation of decision rights to define ex post the content of the contractual obligations, what for brevity we will call here "completion rights". Moreover, we find no within brand variation in the contracts used. All dealers of the same network sign an identical contract, updated yearly.

Second, we find support for the hypothesis that the degree of "contractual asymmetry" varies between the different networks in a manner consistent with the 
differential impact of moral hazard. Manufacturers of higher quality cars and those with larger networks enjoy more discretion over the operation of their networks, both in terms of the completion rights and in their ability to enforce and provide incentives to their dealers. This is consistent with the predictions of a theory relying on the cost of (dealers') moral hazard as the source of variation in the contracts. Moreover, older networks assign more completion and enforcement rights to manufacturers. This may reflect, as we suggest, the fact that longer horizons are related to higher manufacturer reputation (allowing contracts to be more asymmetric). Also, Asian networks exhibit a significantly lower level of centralization of rights in the manufacturer. This is consistent with recent findings in the empirical literature about the reliance of Asian manufacturers on non-verbal, trust based agreements (Sako and Helper, 1998; Holmstrom and Roberts, 1998).

Third, concerning the existence of complementarities between the different elements of the system, we find that all the rights and incentives move together in a manner consistent with the hypothesis that the source of variation in the data is the differential impact of moral hazard in the different networks. After controlling for common sources of variation, part of the covariation disappears, but significant interactions are still observed between instruments. First, the data is consistent with the existence of complementarities between the allocation of completion and termination rights; second, it is also consistent with the existence of complementarities between the allocation of monitoring rights and the intensity of incentives.

The rest of the paper is structured as follows. Section 2 presents a theoretical framework to analyze the relationship between manufacturer and automobile dealers, the elements of the contractual solution, and the sources of variation in these elements. Section 3 reviews the data. Section 4 presents the results and discusses them. Section 5 concludes. 


\section{ANALYTICAL FRAMEWORK}

\subsection{The Dealer Manufacturer Relationship in Automobile Distribution}

Automobile distribution is centered on a vertical relationship between automobile manufacturers and dealers. Manufacturers supply automobiles to dealers, write contracts governing their relationships with them, and police the behavior of the network. Dealers provide sales and after-sale services. In our data, each of them distributes only automobiles for a particular manufacturer. They also provide customers with information on new cars, which requires investment in advertising and in sales staff. Dealers maintain brochures, showrooms, trial cars and a substantial stock of new cars to facilitate inspection and allow for test driving and quick delivery. Moreover, they provide complementary services by acting as insurance and finance brokers as well as dealing with the paperwork involved in car registration. A byproduct of these services is that dealers produce information on customer preferences, which is used by manufacturers to plan car manufacturing. Finally, dealerships also provide the specialized maintenance and repair services required by cars. To supply these services, dealerships maintain specialized technicians, machines and automobile spare parts.

In relation with all these tasks, dealers make choices concerning the price of automobiles, the level of promotional and sales services, and the level and quality of after-sales services. The literature has identified two reasons why these choices will be suboptimal in terms of the maximization of the total value of an integrated dealermanufacturer network. First, there exists a vertical externality. As, for example, Klein and Murphy (1988) have argued, as long as the marginal return of a sale to the dealer is only a part of the total return on an extra sale (which is the sum of both mark-ups), the dealer chooses to sell a lower quantity of automobiles and to provide a lower promotional and sales service level than optimal. 
Second, the existence of horizontal externalities also leads dealers to produce excessively low informational and promotional services. Dealers generate information by investing in publicity and providing certain services. Consumers have incentives to obtain information from the dealers who provide it and then acquire their car from other dealers, who may sell at lower prices but do not provide this information. This freeriding by dealers reduces the total supply of publicity and information, which decreases the final demand for cars (Telser, 1960).

The task of controlling these conflicts through contracts faces two main difficulties, related to contract completion and contract enforcement. First, uncertainty makes it impossible to complete the contract ex ante. Instead, efficient adaptation requires that many terms of exchange, i.e. the precise contractual obligations of the dealers, be established and continuously revised ex post. This is the case, in particular, of the price and number of cars to be sold by each dealer in each year, as well as their sales and service effort. Second, enforcement of the terms of exchange so defined suffers from the fact that many performance variables are costly to observe by the parties and are difficult to verify by potential third party enforcers. In particular, this is the case of sales and service effort. The sale price is also mostly unobservable because the sale of automobiles frequently involves bargaining over price, in order to price discriminate among buyers. Moreover, part of the payment for a new car is often the trade-in of a used vehicle.

\subsection{Contractual Design}

This paper argues that the main role of the contract is to articulate mechanisms to ensure that the dealers choices are consistent with the maximization of the entire network value. These mechanisms are the allocation of completion and enforcement rights to manufacturers and the consequent operation of incentives and quasi-rents to constrain dealers' behavior. 
Rights Assignment. In specifying the dealers' obligations, the contracts do not specify the actual actions that dealers should undertake in the future. Instead, they grant manufacturers the right to choose these actions in future moments. Thus, for example, contracts do not determine the target sales of the dealership, the level of publicity investment by dealers or the appropriate qualification of the sales personnel, but instead they provide for manufacturers to determine and adjust these variables in the future. Given that manufacturers complete in this way many dimensions of the contract, we call these rights to determine ex post the actual content of the performance to be delivered “completion rights".

Contracts also assign "enforcement rights" that allow manufacturers to play a quasijudiciary role in ensuring that dealers fulfil their obligations, including those defined discretionary by the manufacturers in exercise of their completion rights. Enforcement rights include manufacturers' rights to monitor dealers, to terminate the relationship and to establish monetary discount mechanisms to ensure that sales and service targets are met.

This asymmetric assignment of completion and enforcement rights involves a tradeoff between the risk of ex post opportunism on the two sides. More manufacturer discretion in completion and enforcement reduces the risk of moral hazard on the dealer side, while simultaneously intensifying the eventual risk of manufacturer incentive and hold-up hazards (Williamson, 1975, 1979; Klein, Crawford and Alchian, 1978). The latter is a real concern in end-game situations, such as when the manufacturer has bad prospects, so that his discount rate is very high, or when technological changes require a radical transformation of the distribution network. In these cases, it may be difficult for third party enforcers to distinguish opportunistic from disciplinary decisions made by the manufacturer. ${ }^{2}$ As a consequence of this trade-off, contractual asymmetry should

\footnotetext{
${ }^{2}$ Williams (1996) however, shows that terminations by franchisers are infrequent in the US (fewer than $4 \%$ annually) and that the conditional probability of termination decreases significantly as outlet performance increases, the opposite to the relationship predicted if termination were primarily motivated by manufacturer opportunism.
} 
increase with the risk of dealer moral hazard, as determined by the incidence of vertical and horizontal externalities, and with the safeguard that the manufacturer can provide in the form of reputation.

Direct Monetary Incentives. Most dealership networks also rely on direct monetary discounts linked to the achievement of sales targets and the degree of customer satisfaction as measured by client polls. As the agency literature has long argued, these direct monetary incentive schemes may be used to align the incentives of the two parties to the contract. In our context, the implication of the theory is that the intensity of sales and service related monetary incentives should be higher the higher the incidence of the relevant vertical and horizontal externalities.

Quasi Rents. As Klein and Leffler (1981) have argued, the threat of termination together with the existence of a flow of quasi-rents may be sufficient to assure performance in a context of repeated transactions. To this effect, the quasi-rent that the dealer receives must be higher the lower the probability of cheating being detected and punished and the larger the gain from cheating. Notice that, as a consequence of the asymmetric allocation of decision rights, the level of dealers' quasi-rents results, in our case, not from ex ante agreements, but from ex post decisions taken by the manufacturers.

\subsection{Network Characteristics and Risk of Opportunism}

Among the strategic decisions the automobile manufacturer makes are the timing of market entry, the market positioning of the automobiles, and the extent of the dealership network. The contract design is chosen conditional on these decisions. We argue that these strategic choices by the manufacturer determine the scope of opportunistic behavior on the two sides and, as a consequence, the particular combination of contractual solutions chosen by the contract. Our empirical work aims to explain the observed contractual variation as a consequence of the variation in these network characteristics. 
Assuming that entry decisions and car quality choices are exogenous from the point of view of contract design is uncontroversial. In assuming that the network size is an exogenous variable to the choice of contractual design, we rely on the fact that network size is almost entirely a function of the total sales of the brand. ${ }^{3}$ We further assume that total brand sales only enter in the contractual design choice through the dealership structure.

As in any public good context, the larger the network size, as given by the number of dealers in the network the more important the horizontal externality. Therefore, we expect manufacturers to have more discretion to decide and control the behavior of dealers in larger networks; similarly, the intensity of the monetary incentives for the dealer should be higher the larger the dealership network. For the same reasons, we expect dealers to earn higher quasi-rents the higher the number of dealers in the network.

The cost of dealer opportunism also grows with the quality of the car sold. The reason is that the unobservable sales and after-sales service is more important the higher the quality of the car. Thus we expect manufacturers of higher quality brands to be given more discretion on completing the contract and enforcing it. Moreover, we also expect the intensity of sales and service related monetary incentives to be higher the higher the quality of the car. Finally, dealer quasi-rents put in place to avoid shirking should be higher the higher the quality of the car.

Network size and car quality may also covary with the manufacturer reputation. First, as a number of previous studies have noted (Lafontaine, 1992; Agrawal and Lal, 1995), brand name value increases with the total number of outlets in each network, since brand name value increases as more people are exposed to the brand. Moreover,

\footnotetext{
${ }^{3}$ Automobile sales by each brand explains $82 \%$ of the variation in size of the dealership networks. The regression results of the number of dealers on the total sales in money terms in 1995, with the standard errors in parenthesis, are as follows:

Number of Dealers in Network $i=65.41527+.0003265$ Sales of Network, $(7.783622) \quad(.0000341)$

with $\mathrm{R}^{2}=0.8207$.
} 
the 'externalities' generated by an expropriatory conduct by the manufacturer also grow with the number of dealers exposed to it. Second, the average quality of the automobiles sold could also be correlated with the manufacturer reputational capital. Clearly, manufacturers who sell more expensive cars incur higher costs with their customers if the relationship with their dealers deteriorates.

Thus, due to both to the higher risk of dealer moral hazard and the lower risk of dealer expropriation, we expect more decision rights to be allocated to the manufacturer the larger the network and the higher the average price of the automobiles sold. This is because both variables have the effect of increasing the risk of dealer moral hazard (increasing the benefits of manufacturer discretion) and decreasing the probability of expropriation (decreasing the costs of manufacturer discretion).

A third variable that will influence the balance of risk of opportunistic behavior is the age of the network. This has few consequences for the risk of dealers' moral hazard. It does however have implications for the reputational capital of the manufacturer: a longer lasting relationship allows for more reputational capital to be created, as it increases the potential for a cooperative outcome to come about. ${ }^{4}$ As a consequence, we expect manufacturers to be allocated more contractual rights in older networks.

Alternative hypotheses to the one we advance may be used to explain the contractual design. One such hypotheses would argue that the variation in contract design is essentially random variation, and that chance, rather than the scope of opportunistic behavior, determines contractual choices. Such an explanation would not predict the existence of any link between the assignment of decision rights and the automobile price, the dealership size and the age of the network. Thus our data allows us to easily differentiate this explanation from the one we offer.

A second alternative hypothesis would agree that contractual variation is systematic, but would argue that it results from differences in the relative bargaining power of

\footnotetext{
${ }^{4}$ We are implicitly assuming that the time a relationship has lasted is a predictor of the time it will still last.
} 
manufacturers and dealers in different networks. Explanations of this kind could be constructed that would make some but not all of the same predictions as an explanation in terms of the risk of opportunistic behavior. For example, if manufacturer bargaining power increases with the length of the relationship as the specific physical and human capital invested by dealers increases, then a bargaining power hypothesis may predict more decision rights being granted to manufacturers in older networks.

Thus some predictions of a bargaining power-based explanation for contractual design may coincide to the one we offer, making it difficult to differentiate bargaining power and efficiency explanations for contractual variation. The efficiency hypothesis and the bargaining power hypotheses part company completely, however, concerning network profitability. An explanation based on bargaining power would predict that, when the bargaining power of the manufacturer is larger, his ability to extract rents from the dealer is larger. Thus if price, network size and age of the network increase manufacturer bargaining power, they should also decrease dealer profitability, all other things constant. On the other hand, a larger risk of opportunistic behavior by dealers implies that higher price and larger networks are associated with larger dealer quasi rents. Thus data on dealer profitability together with contractual data may help us to differentiate the two hypotheses.

\subsection{Complementarities and Substitutabilities Between Contractual Elements}

We have argued that all elements of the contract respond to the same factors. There exist reasons on theoretical grounds to suspect that the contract is a system of interdependent choices, so that changes in one choice will necessarily imply changes in the other. Not only are all elements of the contract likely to respond to the same factors, but the inclusion of some element (e.g., more asymmetric completion) may either require or preclude that of some other element (e.g., more or less monitoring).

As we shall see, formulating tight hypotheses about these complementarities or substitutabilities between the different mechanisms available is fraught with problems. 
The question of whether and to what extent these choices actually interact with each other is an important one, however, and it ultimately requires an empirical answer.

Completion rights and the enforcement and incentive system: The basic economic analysis of the relation between completion rights and enforcement rights can be derived from the analysis of Milgrom and Roberts (1992: 412) and Jensen and Meckling (1995). ${ }^{5}$ They argue that incentive intensity (in our context, the whole enforcement and incentive system) is complementary with agent discretion. More decentralized decision rights must lead to higher powered incentives, as agency problems become more important the more discretion the agent has. In our context we observe manufacturer discretion, the opposite of dealer discretion, and a complete enforcement and incentive system, rather than simply monetary incentives. Thus, from these theories, we would expect that the lower the manufacturer discretion in completion, the more intense must be the incentive provided by the whole monitoring, termination and incentive systems.

An alternative hypothesis can be derived, however, by recognizing that determining obligations without corresponding mechanisms to enforce these obligations is meaningless. Certainly, the legal system plays a role here. But to the extent that second party enforcement also plays an important role in these relations, more manufacturer completion rights, which are rights to establish dealer obligations, may require more self-enforcement rights, i.e. rights to implement monitoring and incentive systems and to terminate the relationship. This hypothesis leads us to expect more intense monitoring, termination and incentives the higher the manufacturer discretion in completion.

Monitoring and termination/monetary incentives. On the relation between monitoring and termination and monetary incentives, the main existing theoretical result is what has come to be called (Milgrom and Roberts 1992: 226) the monitoring intensity principle, which states that more monitoring should be undertaken the more intense are

\footnotetext{
${ }^{5}$ While their analysis deals directly with the rights assignment within a firm, the main ideas can be readily generalized to the between firms context of the distribution contracts we study.
} 
the incentives. Translated into the contractual rights assignment in our context, we expect monitoring to be complementary with termination and/or monetary discounts. ${ }^{6}$

Termination and monetary incentives. We expect the different incentive and enforcement mechanisms to be substitutes: if appropriate incentives are provided through the threat of expropriation of quasi-rents implicit in termination (Klein and Leffler, 1981; Klein and Murphy, 1988, 1997), then explicit monetary discounts should be less important.

Sales and service related monetary incentives. A multitasking set up, such as the one proposed by Holmstrom and Milgrom (1994), would predict that the level of incentives provided by different types of mechanisms is complementary. If more sales related discounts are provided, the dealer may decrease the service effort, and service related discounts must increase to compensate this reaction.

Empirically testing these hypotheses is fraught with problems. First, because in some instances the theory provides ambiguous guidance about what we should find. Second, because the empirical existence of complementarities depends on the source of variation in the data, and the vector of choices may not be associated with respect to the changes in the impact of moral hazard that we are exploring. And finally, because the existence of unaccounted variables observed by the contract designers but not by the econometrician may cause co-movements in the contractual choices when no interactions actually exist.

In spite of these difficulties, we explore the existence of comovements in the last part of the empirical section. The spirit of this investigation is to further our understanding of the data and to guide further theory development, rather than to actually test any specific hypotheses.

\footnotetext{
${ }^{6}$ The monitoring intensity principle is derived in a world of complete contracting, but we have no reason to believe that the sign of the prediction should be affected by whether contracts are or not complete.
} 


\section{THE DATA}

The empirical analysis is based on the dealership contracts of the 23 main networks operating in Spain, which represent $99.3 \%$ of the market and all of the important multinational firms. We complement the contractual data with data on the characteristics of the dealerships of the different networks, including particularly the number of dealerships, the age of the network, the price of the automobiles sold by the network and the average profitability of the dealerships in the network, as measured by the average return on sales. ${ }^{7}$

A first striking feature of the data is that the contracts present no variance between dealers of the same brands. They are contracts of adhesion, updated yearly by the manufacturer and circulated to all members of the network for their signature. ${ }^{8}$ Thus contracts do not respond to the within brand variation in dealer's characteristics, such as their reputation or the time they joined the network.

All contracts assign dealers certain rights. This allocation, mostly made implicitly by not including limiting rights in the contract, defines a core set of dealers' rights common to all the networks. In particular, dealers set prices of cars sold, always below the ceilings established periodically by the manufacturers. They also decide on the quantity and models of automobiles they order from the manufacturers. Manufacturers can however force them to sell some models (quantity forcing), in exceptional circumstances. Finally dealers may choose, subject to manufacturers approval, the price of after-sale services, the tools for the after-sale service, the local marketing campaigns and the location of the dealership.

\footnotetext{
${ }^{7}$ See the appendix for a more extensive data collection description and the descriptive statistics of these variables. Readers interested in a more complete description of the individual contractual clauses should refer to Arruñada and Vázquez (1999).

${ }^{8}$ Lafontaine and Shaw (1996) find a different pattern: They observe contract terms to be fixed for all those franchisees who joined at a point in time, but then stay constant for them over time. The literature has explained this fixity as a consequence of double sided moral hazard (Bhattacharyya and Lafontaine, 1995) and of the cost of designing different contracts (Holmstrom and Milgrom, 1987).
} 
As Table 1 shows, contract variation in manufacturer completion rights between networks is small. Of the 16 types of dealership variables that the contracts potentially assign to manufacturers, only 4 show some variation: those affecting the level of training of the sales force, the number of trial vehicles, the determination of a minimum capital by the manufacturer and the right to limit dealer sales outside of his own territory.

\section{[Note: Table 1 here, with list of contract clauses]}

All contracts assign certain monitoring rights to manufacturers. In particular, as Table 1 shows, they are authorized to directly inspect the inputs of the dealership (machinery, personnel, etc.) and to measure dealer performance in terms of achievement of sales targets. Most contracts also allow dealers to monitor customer satisfaction, as measured by polls. Finally, most manufacturers may monitor dealers financial performance by regularly auditing their financial statements.

Concerning termination rights, all contracts explicitly assign manufacturers the right to terminate the contracts when the dealer infringes certain duties. In particular, the repeated breach of sales and service targets, the change in the ownership of the dealership or the bankruptcy of the dealership are always reasons for automatic termination. Other circumstances, such as management changes or disagreements among partners or managers also trigger termination rights in some networks. ${ }^{9}$

A particularly salient right assigned by the contracts is the right to establish dealers' annual sales targets. Targets are defined in terms of the market share that the dealer must achieve in the relevant local market and then communicated to dealers in the form of the sales volume they must achieve. They are set every year on January, relying on forecasts elaborated by manufacturers based on historical sales data in the dealer's market and at the national level. The numerical target may be later revised if either the

\footnotetext{
${ }^{9}$ The inclusion of termination at will clauses in contracts would make superfluous the enumeration of individual reasons for termination. However, both the European legislation and the general rules of the Spanish contract law substantially limit the scope for termination at will.
} 
aggregate sales of automobiles or the national market share of the brand are lower than forecasted, providing some partial insurance for the dealers.

These sales targets are linked in 20 of the networks to substantial discounts on the wholesale automobile price paid by dealers depending on the degree to which they achieve them. ${ }^{10}$ The first row in Table 2 shows the across-network average quantity related discounts applied to the prices of all vehicles acquired by dealers between 1993 and 1995. For example, dealers who met their annual sales targets received a mean discount of $2.38 \%$ of the price of all the automobiles they had acquired from the manufacturer in that year. The importance of these discounts is such that most dealers would be unable to obtain any profits if they were not receiving them. ${ }^{11}$

Likewise, in 13 of the networks, manufacturers set service targets and dealers may obtain discounts in accordance with customer satisfaction as measured through client polls. Service-related discounts are smaller but also crucial to dealers' profitability. When customer satisfaction is highest, the mean discount on this concept that dealers could obtain annually was $0.73 \%$ of the price of all automobiles they acquired from the manufacturers. Note that, since the discount falls on all the units sold, the discount increases more than proportionally with customer satisfaction.

\section{[Note: Table 2 here, describing sales and service discounts]}

Both of these discounts show a "stair-step" pattern. Reaching the next stair (for example, selling the car that gets the dealer to $80 \%$ of his sales target) produces a decrease in the price paid by the dealer for all of the units sold up to that level. As a consequence of this pattern, the marginal price paid by each dealer is a decreasing function of the number of cars sold by this particular dealer.

\footnotetext{
${ }^{10}$ The three networks that did not use sales discounts declared in interviews that they do set and follow up sales targets, however, which they use only to impose disciplinary termination and to justify it before third party enforcers. Thus these three networks rely exclusively on termination to provide incentives to their dealers.

${ }^{11}$ Compare the discounts with the average return on sales, which was $0.35 \%$ in 1993 , $0.66 \%$ in 1994, and 1.1\% in 1995 (See table A2 in the Appendix A2). Note that these ROS data are in the same range as the 1997 for USA (1.4), Japan (0.4) and UK (1.5) (Dickinson, Dembkowski and Shah, 1998).
} 


\section{RESULTS: EXPLAINING THE JOINT ASSIGNMENT OF COMPLETION AND ENFORCEMENT}

\section{RIGHTS AND THE USE OF MONETARY INCENTIVES}

In this section we test the predictions of the theory for the allocation of rights, the use of incentives, and the existence of quasi-rents. We then go on to study the interactions between these choices.

\subsection{Cross-sectional Variation in Manufacturer Completion and Enforcement Rights: Agency Considerations}

The theory predicts that the level of discretion available to manufacturers should increase with the risk of dealer moral hazard, as determined by the incidence of vertical and horizontal externalities, and with the safeguard that the manufacturer can provide in the form of reputation. We investigate here this hypothesis.

Dependent Variables. We obtained predictions from the theory in section 2 concerning the level of manufacturer discretion both in particular domains and in the assignment of particular rights. We construct an index of the manufacturer discretion in each particular domain by simply adding the number of rights in that domain allocated to the manufacturer. Thus we measure allocation of completion, monitoring and termination rights in brand $i$ by the number of such rights assigned by the contract of that brand to the manufacturer. We measure the discretion of the manufacturer $i$ in enforcement by the number of monitoring and termination rights assigned to the manufacturer. Adding up these rights presents some problems. However, it allows us to provide a comprehensive measure of contract asymmetry in different domains (i.e., completion, monitoring and termination), as the rights within each of these three domains have a related purpose, and permits us to focus on the object of interest in this study, namely the discretion the manufacturer has in completion, monitoring and termination. Moreover, we check the consistency of our measure by examining the 
variation of all of the individual rights. As we show in Section 4.4, they indeed vary in the same direction as the aggregates.

Independent Variables. As we argued in the theory, we are interested in the effects of three variables on the assignment of decision rights: the quality of the automobiles sold, the number of dealerships in the network and the length of the relationship. We proxy the quality of the automobiles by their average price. We also include in the analysis controls for the continent of origin of the manufacturer. Here the main concern is to take into account the fact that Asian firms are usually found to be less reliant on formal contractual mechanisms (Sako and Helper, 1998; Holmstrom and Roberts, 1998). As a consequence, we would expect Asian dealers to assign explicitly a smaller number of rights to the manufacturer.

Estimation. From the theory presented in section 3, the discretion of the manufacturer is a function of the agency costs and the reputation of the manufacturer. We run the following OLS regressions for the clauses of the different types: ${ }^{12}$

Number of Rights of type $j$ of Manufacturer of Brand $i=\beta_{0}+\beta_{1}$ Average Price of Car of Brand $i+\beta_{2}$ Number of Dealers in Network of Brand $i+\beta_{3} \log$ Number of Years Brand i Network is in Operation + Continent Dummies.

Since these dependent variables are count variables, and for each of them there exists a known minimum ( 0 clauses of type $j$ used by brand $i$ ) and maximum (all clauses of type $j$ used by brand $i$ ) number of clauses, the suitability of OLS in this context is questionable. To ensure the validity of the results under these circumstances, we repeat the estimation by maximum likelihood. These estimates assume that for each brand, we observe the results of $N_{i}$ trials, where a success in a trial is the presence of an individual clause. Calling $P_{i j}$ the proportion of clauses of type $i$ used in the contract by brand $j$, the assumption required for this estimation method is that

$$
P_{i}=F(\boldsymbol{\beta} \boldsymbol{x})+\varepsilon \text {, with } E\left(\varepsilon_{i}\right)=0 \text {, and } \operatorname{Var}\left[\varepsilon_{i}\right]=F(\boldsymbol{\beta} \boldsymbol{x})(\boldsymbol{1}-F(\boldsymbol{\beta} \boldsymbol{x})) / n_{i} \text {. }
$$

\footnotetext{
${ }^{12}$ See the data appendix for the descriptive statistics of the independent variables.
} 
We do present both tables, however, since the OLS estimates are easier to interpret, and do not rely for the significance of the coefficients on the large number of observations that the probit estimates imply. Moreover, we check for the consistency of the results using a linear probability model estimated by weighted least squares to deal with the heteroskedasticity that exists because of the binary nature of the data. We estimate the probability that right $i$ is assigned to the manufacturer for each individual right as a function of the above variables.

Results. We present the empirical analysis of the manufacturer discretion in Table 3. For each discretion variable we present two specifications. The baseline specification includes the three main proxies. The second row for each variable includes controls for the region of origin of the manufacturer.

\section{[Note: Table 3 here, with allocation of rights]}

The effects of the price, dealer, age and Asia variables are consistent with the predictions of the incentive theory enunciated above. They are also consistent across specifications and across regressions, and, despite the relatively small number of observations, they are significant in most of the regressions on the number of clauses. The exception to this is the age coefficient, which becomes insignificant in all regressions when the Asia control is added. Also quite remarkably, the significance of the main explanatory variables does not decrease substantially as continent controls are added. On their own, the average price sold, the number of dealers in the network and the age of the network explain around $70 \%$ of the variation in the allocation of completion rights by these contracts.

\section{[Note: Table 4 here, with allocation of rights by MLE]}

The regressors are also economically significant. An increase in price of automobiles of one standard deviation (Pta- $1.93 \mathrm{~m}$.) increases manufacturer discretion on average in 2 dimensions. Similarly, an increase of one standard deviation of the number of dealers (65 dealers) also adds on average 2 rights to the manufacturer discretion. Finally, an 
increase in the Log Age in one standard deviation (.88) increases manufacturer discretion by 1 clause.

The main observation that can be derived from using MLE methods to estimate the relation between decision rights and network characteristics as showed in Table 4 is that the results of such a procedure are entirely consistent with those in Table 3 . None of the 28 signs of the dependent variables is altered by the change in methods. Price and number of dealerships are clear determinants of the use of each individual clause. The age of the network still seems to be a factor, although in none of the estimates does it enter significantly.

Our confidence in these results is increased by the analysis of the individual clause variation presented in Table $5 .^{13}$ The signs of the individual effects are overwhelmingly the ones that Table 4 has led us to expect: of 60 possible signs (15 regressions times 4 independent variables), only 4 are different than in Tables 3 and 4 and all of those 4 are insignificantly different than 0 . As in Tables 3 and 4, particularly robust appear the results on Car Price, Number of Dealers in the Network, and the Asia dummy.

[Note: Table 5 here, with variation of individual rights]

\subsection{The Use of Discounts}

The theory in Section 3 predicts that stronger monetary incentives should be used when the cost of dealer opportunism is higher. Also, higher manufacturer reputation should lead to stronger incentive intensity, as the ability of the manufacturer to opportunistically reduce the dealer's income is larger when discounts are a more important component of dealers income, given the ability of the manufacturer to manipulate sales targets. ${ }^{14}$

${ }^{13}$ Given the relatively small sample size, we use only the Asia control, since we found the European control to be entirely insignificant in all of our Table 3 regressions.

${ }^{14}$ While, in the absence of price discounts, the manufacturer may influence the dealers' profitability by altering the price charged per car, this affects the entire network and 
Dependent Variables. The discount level is in itself an imperfect measure of incentive intensity. Provided that sales fall between the minimum and maximum quantity of cars sold necessary to obtain a discount, a dealer faces identical incentives and obtains the same income with higher prices paid and higher average discounts as with lower prices and lower average discounts. For this reason, the discount range is likely to be the best available measure of incentive intensity for a wide range of outcomes. However, to avoid eventual conflicts between the different indicators, we construct and use several alternative measures of incentive intensity: the use of sales and/or service discounts, the level of each of these discounts, and the range of discounts attainable. For both the level and range, we differentiate between sales and service discounts.

Estimation. We use an ordered logit to estimate the relation between the use of discounts (0, 1 if either sales or services used and 2 if both) and our independent variables. We use a tobit to analyze the variation on the discount rages, as at their lowest the contracts that provide lower monetary incentive intensity have 0 discounts.

\section{[Note: Table 6 here, with intensity of monetary incentives]}

Results. The most remarkable fact about Table 6 is its consistency with the results on the contractual clauses. The same variables that explain the degree of asymmetry in the allocation of decision rights explain here the use and intensity of the monetary incentives provided. The coefficients are, with the exception of the Network Age and (once) the Average Price, not statistically significant. Their signs are for the most part entirely consistent with the theoretical predictions from section 3 .

The lack of predictive power of the sale discount specifications (the second and three sets of regressions in Table 6) is puzzling, particularly compared to the high significance levels found in the rest of our analyses. The pseudo- $\mathrm{R}^{2}$ for these estimations is extremely low, suggesting that the agency-related variables that explain

(since it creates a larger double marginalization problem) it has the potential to damage as much the manufacturer himself as the dealers. 
the use of discounts fail to account for the variability of the level and range of sales discount. Alternatively, there may exist some hidden heterogeneity in the strictness of the sales targets across brands. If some manufacturers set very high targets, so that most of their dealers barely achieve the lower step of the discount schedule, while other manufacturers set low targets, so that most dealers achieve over target sales, then the meaning of our range and level of sale discounts is different for different brands. Figuring out whether this is the case would require knowing the ex post distribution of discounts for different manufacturers. Regrettably, this data is not available.

\subsection{Quasi-Rents}

To test Klein and Leffler's (1981) hypothesis that the flow of quasi-rents to the dealers combined with termination provides a self-enforcing device, Table 7 presents a panel regression of the profitability during three years of the automobile dealerships. We use year dummies, as the observations are at substantially different points in the cycle. Profitability is (imperfectly) proxied here by the return on sales, the standard profitability measure in the industry. ${ }^{15}$

\section{[Table 7 Here]}

In the presence of more important agency problems the quasi-rents flow must be larger to dissuade dealers from opportunistic behavior. Table 7 provides clear support for this hypothesis in one instance: higher price dealerships have higher profitability, as measured by their return on sales. The coefficient is also economically relevant, as a standard deviation change in the price (Pta. $2 \mathrm{~m}$ ) leads to a 6 point increase in ROS. The other coefficients in which our study is interested are insignificantly different from 0 , although their signs are as we would expect from the theory. First, profitability

${ }^{15}$ Caution must be used in interpreting these results. First, the short length of the panel limits the usefulness of the discussion, as the cycle could have different effects on different networks. Moreover, identifying different in ROS as differences in quasi-rents is also problematic. 
increases with horizontal externalities, as measured by the size of the dealership network. Second, it decreases with the age of the network.

The results of this regression also provide some additional evidence on an alternative explanation of the data to the one we have suggested here: the possibility that the variation in contractual asymmetry responds to the differential bargaining power of the different automobile manufacturers. The coefficients that predict the existence of quasirents are the same ones that predict the existence of asymmetry, and suggest that those networks that have a more asymmetric position actually enjoy higher profitability. This is not as would be predicted by an explanation of the contractual design based on the relative bargaining power of the parties.

\subsection{Complementarities and Substitutabilities}

As section 2 has argued, there are reasons to believe that there exist interactions between the different elements of the system. Table 8 presents the unconditional correlations between each pair of decision variables. These unconditional correlations are all positive with the exception of those between the realized quasi-rents and the rest of the variables, suggesting that a change in any contractual variable is related with a change in the same direction of any of the others. While Table 8 is consistent with the existence of complementarities between contractual decision variables, it cannot help to reject the hypothesis that each contractual choice is unrelated to any other choice. Comovements in all the contractual variables may simply respond to movements in the same underlying variable. As we have seen during the previous sections, it is indeed the case that all of these variables respond to similar considerations.

[Note: Table 8 here, with unconditional correlations] 
Two methodologies have been used by the literature to solve this problem. ${ }^{16}$ Some authors, starting with Arora and Gambardella (1990) have tested whether the practices are correlated, conditional on the observables. Others, notably recently Ichiniowski, Shaw and Prennushi (1997) directly estimate a production function and then test whether the interactions between practices are positive.

In what follows we choose to use the first approach. The reason is that we do not have sufficient information to confidently estimate a production function for the dealership networks, nor do we have a sufficiently narrow definition of output. The downside of the conditional correlation measures is that, if there are variables which are unobserved to us but observed to the firm which favor the use of some practices, we will have upward biased estimates of the conditional correlation. It will appear that different practices are complementary when, in fact, they are simply moving together as a result of the impact of a third variable unknown to us.

Table 9 presents the conditional correlations between the different measures of discretion. They have been calculated as the correlations between the residuals of the contract regressions, the monetary incentive Tobits, and the profitability panel. Since the estimation of the monetary incentive equations relies on non-linear MLE methods, we use the generalized residuals proposed by Bourieroux, Monfort, Renault and Trognon (1987).

\section{[Note: Table 9 here, with conditional correlations]}

Controlling for common sources of variation reduces the covariation from the one that could be observed in Table 8. This suggests that part of the covariation that could be observed was the consequence of a common response of the different contractual elements to the same problem, namely the risk of moral hazard. The evidence points, however, to the existence of interdependencies between some elements of the system. In

\footnotetext{
${ }^{16}$ See Athey and Stern (1998) for an excellent discussion of the issues at stake. The computationally intensive method they propose to go around this problem is, however, not applicable to our case given the size of our data set.
} 
particular, Table 9 points to complementarities between completion and termination rights, and between monitoring and incentive intensity.

The evidence on the positive conditional correlation between completion and termination rights may suggest that manufacturer discretion in termination, a dimension of enforcement, is present when the manufacturer also has more scope for decision making. With the caveats on interpretation of this conditional correlation mentioned at the end of section 2.4, this result contradicts the standard economic interpretation, which predicted that stronger enforcement or incentive intensity should go together with dealer discretion. The result is consistent, however, with the alternative hypothesis we advanced, which recognizes the need for the right to establish obligations to covary with the right to enforce those obligations.

Also, the second column of Table 9 suggests that it is indeed the case that more monitoring intensity covaries with more incentive intensity, as measured by either any of the monetary discounts or by termination rights. Only in one case is this correlation significant at the $95 \%$ level, ${ }^{17}$ but four of the correlations would be significant at the $85 \%$ level. This is consistent with what the theory would lead us to predict. As moral hazard increases, incentive provision needs to be stronger, and this implies that monitoring intensity must increase. ${ }^{18}$

The last four rows of Table 9 present the evidence on the use of sales and service discounts. The only coefficients that are significantly different from zero relate the level and the range of discounts, which is of limited economic interest and suggests simply that both are measures of incentive intensity. There is no evidence, however, for the existence of comovements between sales and service discounts.

\footnotetext{
${ }^{17}$ The evidence on this relation is, however, weakened by the fact that the sale discount equations present the lowest (pseudo) $\mathrm{R}^{2}$ in our whole analysis. It is easy to argue that, if we had been able to explain more fully the variation in the range of sale discounts the coefficient would have been eliminated.

${ }^{18}$ Note that two of the three monitoring rights that present some variation in the data are rights to inspect variables that are relevant to the provision of sales related discounts: the right to inspect dealer accounting data and the right to audit the dealer accounting.
} 
We find the results illuminating. First, there is evidence consistent with the hypothesis that the whole system, with the possible exception of the quasi-rents, is designed to solve a similar set of problems. Second, we find evidence of some complementarities between the different instruments, in particular between completion and termination rights, and between monitoring and discounts. Finally, the evidence on the comovements of rights assignment, even after controlling for common sources of variation, is consistent with the hypothesis that the source of variation in the data is the differential impact of moral hazard for the different brands.

\section{CONCLUSION}

This paper has studied empirically the entire system of allocation of rights and monetary incentives in franchising contracts. The system of allocation of rights does not actually specify the terms of the performance that the parties commit to delivering. Instead, the contracts substantially restrict the decision rights of dealers, and grant manufacturers extensive completion and enforcement powers, converting the manufacturers in a sort of quasi-judiciary instance.

We find that this assignment of rights and incentives is consistent with efficiency considerations. When the cost of dealer moral hazard is higher and the risk of manufacturer opportunism is lower as a consequence of his reputation, manufacturers enjoy larger discretion in both determining the desired performance from the dealers in their network and in using mechanisms such as monitoring, termination and monetary incentives to ensure this performance is provided.

The paper has also explored the existence of interdependencies between the different elements of the system. The use of all instruments seems to respond to the same considerations, as the same variables influence with the same signs the use of the different instruments. After controlling for common sources of variation, part of the covariation disappears, but significant interactions are still observed between 
instruments. In particular, the results are consistent with the hypothesis that contract completion and termination rights are complements, and point in the direction of the monitoring intensity principle, according to which monitoring and incentive intensity are also complements.

As we have pointed out, an important aspect of the logic of the contractual and organizational design structure we observe does not conform to the idea of a contract as a set of vertical restrains usual in the literature (e.g. Mathewson and Winter, 1985). Instead, the contract design assigns a set of rights to manufacturers that allow them to behave as an internal judge in what is, after all, a relationship between two independently-owned business. ${ }^{19}$

What, in our view, the existing theory fails to consider is the ability of the parties to choose between the use of internal or external mechanisms of contract completion and enforcement. The main actors in the economic transactions, the manufacturer and the dealer in this case, have a remarkable informative advantage with respect to third parties, judges included. Our evidence suggests that when the party with the better information reaches a position of impartiality (safeguarded by reputation or expectations of repeated contracting), the contractors decide that that party should act as a judge of first instance. As such, the task of this party is to define ex post those obligations that are hard to define ex ante, fitting the content of the exchange to the changes that have taken place; distributing unexpected losses and gains; evaluating if each one has fulfilled or not its obligations; and, even, imposing sanctions for breach of contract.

Our analysis has focused intentionally on examining the logic of these selfenforcement mechanisms, such as they are articulated in the contracts. This does not mean that legal and judicial institutions play no role. On the contrary, the contracts are partly constrained by mandatory rules, and termination decisions are often litigated.

${ }^{19}$ A recent survey by Masten (1998) rightly points out this tension: economic theories of contracting, for the most part, give little explicit attention to enforcement issues, the presumption being that the courts will make sure that (subject only to verifiability constraints) that whatever terms contracting parties arrive at are fulfilled. 
Investigating the effect of these constraints on the contracts is a matter that we plan to undertake in future, cross country, research. 


\section{REFERENCES}

ARORA, A., and A. GAMBARDELLA (1990), "Complementarity and External Linkages: the Strategies of the Large Firms in Biotechnology," Journal of Industrial Economics, 38: 361-379.

ARROW, K. J. (1985), "The Economics of Agency," in J.W. Pratt and R. J. Zeckhauser, eds. Principals and Agents: The Structure of Business, Harvard Business School Research Colloquium series, Boston: Harvard Business School Press.

ARRUÑADA, B., and L. VÁZQUEZ (1999), "Ownership and Performance in the Automobile Distribution Industry," Universitat Pompeu Fabra, Economics Working Paper, 348.

ATHEY, S., and S. STERN (1998), "An Empirical Framework for Testing Theories about Complementarity in Organizational Design,” NBER Working Paper.

BHATTACHARYYA, S., and F. LAFONTAINE (1995), "Double-Sided Moral Hazard and the Nature of Share Contracts," Rand Journal of Economics, 26: 761-781.

BOURIEROUX, C., A. MONFORT, E. RENAULT, and A. TROGNON (1987), "Generalized Residuals," Journal of Econometrics, 34: 5-32.

BRICKLEY, J. A. (1998), "Incentive Conflicts and Contractual Restraints: Evidence from Franchising," University of Rochester, Bradley Policy Research Center Working Paper.

BRICKLEY, J. A., and F. H. DARK (1987), "The Choice of Organizational Form: The Case of Franchising," Journal of Financial Economics, 18: 401-420.

BRICKLEY, J. A., F. H. DARK, and M. S. WEISBACH (1991), "The Economic Effects of Franchise Termination Laws," Journal of Law and Economics, 34: 101132.

CROCKER, K. J., and K. K. REYNOLDS (1993), "The Efficiency of Incomplete Contracts: an Empirical Analysis of Air Force Engine Procurement," Rand Journal of Economics, 24: 126-145.

DICKINSON, J., S. DEMBKOWSKI, and C. SHAH (1998), The Future of Automobile Distribution, Financial Times Business Ltd., London.

DNES A. W. (1996), "The Economic Analysis of Franchise Contracts," Journal of Institutional and Theoretical Economics, 152: 297-324. 
FREIXAS, X., R. GUESNERIE, and J. TIROLE (1985), "Planning Under Incomplete Information and the Ratchet Effect," Review of Economic Studies, 52: 173-192.

GOLDBERG, P. K. (1996), "Dealer Price Discrimination in New Car Purchases: Evidence from the Consumer Expenditure Survey," Journal of Political Economy, 104: $622-654$.

GOMPERS, P., and J. LERNER (1996), "The Use of Covenants: An Empirical Analysis of Venture Partnership Agreements," Journal of Law and Economics, 39: 463-499.

HARRIS, M., and A. RAVIV (1979), "Optimal Incentive Contracts with Imperfect Information." Journal of Economic Theory, 20: 231-259.

HOLMSTROM, B. (1979), "Moral Hazard and Observability," Bell Journal of Economics, 10: 74-91.

HOLMSTROM, B., and P. MILGROM (1987), "Aggregation and Linearity in the Provision of Intertemporal Incentives," Econometrica, 55: 303-328.

HOLMSTROM, B., and P. MILGROM (1994), "The Firm as an Incentive System," American Economic Review, 84: 972-991.

ICHNIOWSKI, C., K. SHAW, and G. PRENNUSHI (1997), “The Effects of Human Resource Management Practices on Productivity," American Economic Review, 87: 291-313.

JENSEN, M. C., and W. H. MECKLING (1995), "Specific and General Knowledge, and Organizational Structure," Journal of Applied Corporate Finance, 8: 2, 4-18.

KAPLAN, S. N., and P. STRÖMBERG (1999), "Financial Contracting Theory Meets the Real World: An Empirical Analysis of Venture Capital Contracts," Mimeo, Graduate School of Business, The University of Chicago.

KLEIN, B. (1980), “Transaction Cost Determinants of 'Unfair' Contractual Arrangements," American Economic Review Papers and Proceedings, 70: 356362.

KLEIN, B. (1995), "The Economics of Franchise Contracts," Journal of Corporate Finance: Contracting, Governance and Organization, 2: 9-38.

KLEIN, B. (1996), "Why Hold-ups Occur: The Self-enforcing Range of Contractual Relations," Economic Inquiry, 34: 444-463.

KLEIN, B., and K. LEFFLER (1981), "The Role of Market Forces in Assuring Contractual Performance," Journal of Political Economy, 89: 615-641. 
KLEIN, B., and L. F. SAFT (1985), "The Law and Economics of Franchise Tying Contracts," Journal of Law and Economics, 28: 345-361.

KLEIN, B., and K. M. MURPHY (1988), "Vertical Restraints as Contract Enforcement Mechanisms," Journal of Law and Economics, 31: 265-297.

KLEIN, B., and K. M. MURPHY (1997), "Vertical Integration as a Self-Enforcing Contractual Arrangement," American Economic Review; 87: 415-20.

KRUEGER, A. B. (1991), "Ownership, Agency and Wages: An Examination of Franchising in the Fast Food Industry," Quarterly Journal of Economics, 106: 75101.

LAFONTAINE, F. (1992), "Agency Theory and Franchising: Some Empirical Results," Rand Journal Economics, 23: 263-283.

LAFONTAINE, F. (1993), "Contractual Arrangements as Signaling Devices: Evidence from Franchising," Journal of Law, Economics, and Organization, 9: 256-289.

LAFONTAINE, F., and K. L. SHAW (1996), “The Dynamics of Franchise Contracting: Evidence From Panel Data,” NBER Working Paper 5585.

LAFONTAINE, F., and M. E. SLADE (1998), "Incentive Contracting and the Franchise Decision," NBER Working Paper 6544.

LAL, R. (1990), "Improving Channel Coordination through Franchising," Marketing Science, 9: 299-318.

LUTZ, N. A. (1995), "Ownership Rights and Incentives in Franchising," Journal of Corporate Finance: Contracting, Governance and Organization, 2: 56-74.

MASTEN, S.E. (1998), “Contractual Choice,” in B. Boukaert and G. de Geest (eds.), Encyclopedia of Law \& Economics, Edward Elgar, Cheltenham and Northampton.

MASTEN, S. E., and K. J. CROCKER (1985), "Efficient Adaptation in Long-term Contracts: Take-or-Pay Provisions for Natural Gas," American Economic Review, 75: 1083-93.

MASTEN, S. E., and E. A. SNYDER (1993), "United States v. United Shoe Machinery Corporation: On the Merits," Journal of Law and Economics, 36: 33-70.

MATHEWSON, F., and R. WINTER (1985), "The Economics of Franchise Contracts," Journal of Law and Economics, 28: 503-526.

MATHEWSON, F., and R. WINTER (1994), “Territorial Restrictions in Franchising Contracts" Economic Inquiry, 32: 191-192.

MARVEL, M. (1982), "Exclusive Dealing," Journal of Law and Economics, 25: 1-25. 
MINISTERIO DE JUSTICIA E INTERIOR (1995), Anuario Estadístico General de la $D G T$, Servicio de Estadística, Madrid.

NORTON, S. (1988), “An Empirical Look at Franchising as an Organizational Form,” Journal of Business, 61: 197-217.

PASHIGIAN, B. P. (1961), The Distribution of Automobiles, An Economic Analysis of the Franchise System, Prentice Hall, Englewood Cliffs, NJ.

PRENDERGAST, C. (1999), "The Provision of Incentives in Firms," Journal of Economic Literature, 37: 7-64.

REGULATION (EU) 1.475/95 of the Commission, of June 28, 1995 on the application of Art. 85.3 of the Treaty of the EEC to certain categories agreements for the service and distribution of automobiles, Official Journal of the European Communities, 29 June, 1995: 25-34.

RUBIN, P. H. (1978), "The Theory of the Firm and the Structure of Franchise Contract," Journal of Law and Economics, 21: 223-233.

SEN, K. C. (1993), "The Use of Initial Fees and Royalties in Business Format Franchising," Managerial and Decision Economics, 14: 175-190.

SHEPARD, A. (1993), "Contractual Form, Retail Price, and Asset Characteristics in Gasoline Retailing," Rand Journal of Economics, 24: 58-77.

SLOAN, A. P. (1964), My Years with General Motors, McFadden, New York.

SMITH II, R. L. (1982), "Franchise Regulation: An Economic Analysis of State Restrictions on Automobile Distribution," Journal of Law and Economics, 25: 125-138.

TELSER, L. (1960), "Why Should Manufacturers Want Fair Trade?," Journal of Law and Economics, 3: 86-105.

TELSER, L. (1980), “A Theory of Self-Enforcing Agreements,” Journal of Business, 53: $27-44$.

WILlIAMS, D. L. (1996), "Incomplete Contracting and Ex Post Opportunism: Evidence from Franchise Contract Terminations," UCLA Working Paper.

WILliAMSON, O. E. (1975), Markets and Hierarchies: Analysis and Antitrust Implications, Free Press, New York.

WILLIAMSON O. E. (1979), “Transaction-Cost Economics: The Governance of Contractual Relations," Journal of Law and Economics 22: 233-261 
Table 1. Rights Assigned by Contract to Manufacturers

\begin{tabular}{|c|c|}
\hline Contract Clauses & Mean \\
\hline \multicolumn{2}{|c|}{$\begin{array}{l}\text { 1. Manufacturer ex post completion rights. Contracts in which } \\
\text { Manufacturer has the right to determine: }\end{array}$} \\
\hline Sales targets & 1.00 \\
\hline Size and decor of showroom & 1.00 \\
\hline Publicity investment & 1.00 \\
\hline Stock of new vehicles & 1.00 \\
\hline Size and qualification of sales force & 1.00 \\
\hline Compulsory sales force training & 0.65 \\
\hline Number of trial vehicles & 0.52 \\
\hline Machinery and tools & 1.00 \\
\hline Organization and size of workshop & 1.00 \\
\hline Size and qualification of after-sale personnel & 1.00 \\
\hline Compulsory training of after-sale personnel & 1.00 \\
\hline Quality of spare parts & 1.00 \\
\hline Stock of spare parts & 1.00 \\
\hline Minimum operating capital and net worth & 0.52 \\
\hline Limit sales out of territory ${ }^{a}$ & 0.52 \\
\hline Set maximum authorized price & 1.00 \\
\hline Total number of completion rights & 14.22 \\
\hline \multicolumn{2}{|l|}{ 2. Manufacturer monitoring rights: } \\
\hline Fulfillment of sales targets & 1.00 \\
\hline Direct inspections of dealership & 1.00 \\
\hline Dealer duty to provide accounting data & 0.87 \\
\hline Right to poll dealer clients & 0.74 \\
\hline Right to audit dealer accounting & 0.52 \\
\hline Total number of monitoring rights & 4.13 \\
\hline \multicolumn{2}{|l|}{ 3. Manufacturer termination rights: } \\
\hline Repeated breach of sales and service targets & 1.00 \\
\hline Change in the ownership of the dealership & 1.00 \\
\hline Bankruptcy of the dealership & 1.00 \\
\hline Non-payment to the manufacturer & 1.00 \\
\hline Change of management ${ }^{b}$ & 0.83 \\
\hline Disagreement among partners or managers & 0.61 \\
\hline Change of location ${ }^{c}$ & 0.61 \\
\hline Appointment of liquidator & 0.57 \\
\hline Court verdict $^{d}$ & 0.43 \\
\hline False information ${ }^{\mathrm{e}}$ & 0.35 \\
\hline Loss of control ${ }^{f}$ & 0.09 \\
\hline Dealership closed ${ }^{g}$ & 0.09 \\
\hline Total number of termination rights & 7.57 \\
\hline
\end{tabular}

Notes: ${ }^{\text {a }}$ Sales out of dealer territory not allowed. ${ }^{\mathrm{b}}$ Includes death or disability of dealer. ${ }^{\mathrm{c}}$ Without manufacturer approval. ${ }^{\mathrm{d}}$ Verdict against dealer, partner or manager of the dealership. ${ }^{\mathrm{e}}$ Provision of false information to manufacturer. ${ }^{\mathrm{f}}$ Loss of control of dealership premises. ${ }^{\mathrm{g}}$ Dealership closed for period longer than normal holiday. 
Table 2. Sales and Service Discounts, 1993-1995

\begin{tabular}{|c|c|c|c|c|c|c|c|c|c|c|}
\hline \multicolumn{8}{|c|}{ Discounts established by manufacturers for each target } & \multirow{2}{*}{\multicolumn{3}{|c|}{$\begin{array}{c}\text { Mean discounts actually } \\
\text { attained by dealers, as } \% \\
\text { of price paid. }\end{array}$}} \\
\hline & \multicolumn{7}{|c|}{ Percent of sales target achieved } & & & \\
\hline & $80 \%$ & $85 \%$ & $90 \%$ & $95 \%$ & $100 \%$ & $105 \%$ & $110 \%$ & 1993 & 1994 & 1995 \\
\hline $\begin{array}{l}\text { Maximum sales } \\
\text { discount }\end{array}$ & $1.5 \%$ & $2 \%$ & $2.5 \%$ & $3 \%$ & $3.5 \%$ & $3.5 \%$ & $3.5 \%$ & \multirow{7}{*}{$1.39 \%$} & \multirow{7}{*}{$1.63 \%$} & \multirow{7}{*}{$1.70 \%$} \\
\hline $\begin{array}{l}\text { Minimum sales } \\
\text { discount }\end{array}$ & $0 \%$ & $0 \%$ & $1 \%$ & $1 \%$ & $2 \%$ & $2 \%$ & $2 \%$ & & & \\
\hline \multirow[t]{3}{*}{$\begin{array}{l}\text { Mean of sales } \\
\text { discount schedules }\left(^{*}\right)\end{array}$} & $0.49 \%$ & $0.64 \%$ & $1.51 \%$ & $1.63 \%$ & $2.38 \%$ & $2.40 \%$ & $2.42 \%$ & & & \\
\hline & \multicolumn{7}{|c|}{ Percent of service target achieved } & & & \\
\hline & $70 \%$ & $75 \%$ & $80 \%$ & $85 \%$ & $90 \%$ & $95 \%$ & $100 \%$ & & & \\
\hline $\begin{array}{l}\text { Maximum service } \\
\text { discount }\end{array}$ & $0.7 \%$ & $0.9375 \%$ & $1 \%$ & $1.0625 \%$ & $1.125 \%$ & $1.1875 \%$ & $1.25 \%$ & & & \\
\hline $\begin{array}{l}\text { Minimum service } \\
\text { discount }\end{array}$ & $0 \%$ & $0 \%$ & $0.3 \%$ & $0.325 \%$ & $0.35 \%$ & $0.375 \%$ & $0.4 \%$ & & & \\
\hline $\begin{array}{l}\text { Mean of service } \\
\text { discount schedules }\left(^{*}\right)\end{array}$ & $0.18 \%$ & $0.45 \%$ & $0.55 \%$ & $0.59 \%$ & $0.62 \%$ & $0.67 \%$ & $0.73 \%$ & $0.64 \%$ & $0.63 \%$ & $0.65 \%$ \\
\hline
\end{tabular}

(*) Note: Means conditional on existence of positive discount schedule 
Table 3. Manufacturer Discretion: Ordinary Least Squares Estimates

(Ordinary least squares regressions of a cross-section of contracts)

\begin{tabular}{|c|c|c|c|c|c|c|c|}
\hline \multirow{2}{*}{$\begin{array}{l}\text { Dependent } \\
\text { Variables }\end{array}$} & \multicolumn{5}{|c|}{ Independent Variables } & \multirow[b]{2}{*}{ Intercept } & \multirow{2}{*}{$\begin{array}{l}\text { Adj. } R \\
\text { Sq. }(N)\end{array}$} \\
\hline & $\begin{array}{l}\text { Average } \\
\text { Car Price }\end{array}$ & $\begin{array}{c}\text { Dealers in } \\
\text { Network }\end{array}$ & $\begin{array}{c}\text { Log Age } \\
\text { of Network }\end{array}$ & Asia & Europe & & \\
\hline \multirow[t]{2}{*}{$\begin{array}{l}\text { Completion } \\
\text { Rights }\end{array}$} & $\begin{array}{c}0.473^{\star *} \\
(0.1401)\end{array}$ & $\begin{array}{l}0.0126^{*} \\
(0.0054)\end{array}$ & $\begin{array}{l}0.9368^{* *} \\
(0.3569)\end{array}$ & --- & --- & $\begin{array}{l}8.8133^{* *} \\
(0.7769)\end{array}$ & $\begin{array}{c}0.6963 \\
(23)\end{array}$ \\
\hline & $\begin{array}{l}0.3319^{*} \\
(0.1318)\end{array}$ & $\begin{array}{l}0.0093^{*} \\
(0.0047)\end{array}$ & $\begin{array}{c}0.4219 \\
(0.3384)\end{array}$ & $\begin{array}{c}-1.6697^{\star \star} \\
(0.6090)\end{array}$ & $\begin{array}{c}0.2751 \\
(0.5543)\end{array}$ & $\begin{array}{c}11.4532^{\star *} \\
(0.9925)\end{array}$ & $\begin{array}{c}0.8263 \\
(23)\end{array}$ \\
\hline \multirow[t]{2}{*}{$\begin{array}{l}\text { Monitoring } \\
\text { Rights }\end{array}$} & $\begin{array}{l}0.2919^{* *} \\
(0.0823)\end{array}$ & $\begin{array}{l}0.0084^{* *} \\
(0.0032)\end{array}$ & $\begin{array}{l}0.5218^{*} \\
(0.2097)\end{array}$ & --- & --- & $\begin{array}{c}0.8825 \\
(0.4566)\end{array}$ & $\begin{array}{c}0.7086 \\
(23)\end{array}$ \\
\hline & $\begin{array}{l}0.2306^{*} \\
(0.0958)\end{array}$ & $\begin{array}{l}0.0069^{\star} \\
(0.0034)\end{array}$ & $\begin{array}{c}0.3348 \\
(0.2461)\end{array}$ & $\begin{array}{c}-0.6908 \\
(0.4430)\end{array}$ & $\begin{array}{c}0.0589 \\
(0.4032)\end{array}$ & $\begin{array}{l}1.953^{\star *} \\
(0.722)\end{array}$ & $\begin{array}{c}0.7447 \\
(23)\end{array}$ \\
\hline \multirow[t]{2}{*}{$\begin{array}{l}\text { Termination } \\
\text { Rights }\end{array}$} & $\begin{array}{l}0.8246^{\star \star} \\
(0.2037)\end{array}$ & $\begin{array}{l}0.0258^{* *} \\
(0.0078)\end{array}$ & $\begin{array}{c}0.7590 \\
(0.5188)\end{array}$ & --- & --- & $\begin{array}{c}0.074 \\
(1.1294)\end{array}$ & $\begin{array}{c}0.6872 \\
(23)\end{array}$ \\
\hline & $\begin{array}{c}0.4762^{*} \\
(0.1893)\end{array}$ & $\begin{array}{c}0.0164^{*} \\
(0.0068)\end{array}$ & $\begin{array}{c}0.4115 \\
(0.4861)\end{array}$ & $\begin{array}{c}-3.2702^{* *} \\
(0.8750)\end{array}$ & $\begin{array}{c}-0.8506 \\
(0.7963)\end{array}$ & $\begin{array}{l}4.6945^{\star \star} \\
(1.4259)\end{array}$ & $\begin{array}{c}0.8253 \\
(23)\end{array}$ \\
\hline \multirow{2}{*}{$\begin{array}{l}\text { Total } \\
\text { Number of } \\
\text { Clauses }^{\text {Used }}{ }^{\text {a }}\end{array}$} & $\begin{array}{l}1.5894^{\star *} \\
(0.3606)\end{array}$ & $\begin{array}{l}0.0468^{* *} \\
(0.0138)\end{array}$ & $\begin{array}{l}2.2176^{*} \\
(0.9185)\end{array}$ & --- & --- & $\begin{array}{c}0.7624 \\
(1.9996)\end{array}$ & $\begin{array}{c}0.7624 \\
(23)\end{array}$ \\
\hline & $\begin{array}{c}1.0387^{\star *} \\
(0.306)\end{array}$ & $\begin{array}{l}0.0326^{* *} \\
(0.0109)\end{array}$ & $\begin{array}{c}1.1682 \\
(0.7859)\end{array}$ & $\begin{array}{c}-5.6307^{* *} \\
(1.4146)\end{array}$ & $\begin{array}{c}-0.5166 \\
(1.2875)\end{array}$ & $\begin{array}{l}18.1008^{*} \\
(2.3054)\end{array}$ & $\begin{array}{c}0.8893 \\
(23)\end{array}$ \\
\hline
\end{tabular}

Notes: ${ }^{a}$ Completion, monitoring and termination. ${ }^{\star}$ Significant at $5 \%$ level; ${ }^{* *}$ Significant at $1 \%$ level. 
Table 4. Manufacturer Discretion: Maximum Likelihood Estimates

(Probit estimation of cross section of contracts data by MLE)

\begin{tabular}{|c|c|c|c|c|c|c|c|}
\hline \multirow{2}{*}{$\begin{array}{l}\text { Dependent } \\
\text { Variables }\end{array}$} & \multicolumn{5}{|c|}{ Independent Variables } & \multirow[b]{2}{*}{ Intercept } & \multirow{2}{*}{$\begin{array}{l}\text { Pseudo-R } \\
\text { Sq.(N) }\end{array}$} \\
\hline & $\begin{array}{l}\text { Average } \\
\text { Car Price }\end{array}$ & $\begin{array}{c}\text { Dealers in } \\
\text { Network }\end{array}$ & $\begin{array}{c}\text { Log Age } \\
\text { of Network }\end{array}$ & Asia & Europe & & \\
\hline \multirow[t]{2}{*}{$\begin{array}{l}\text { Completion } \\
\text { Rights }\end{array}$} & $\begin{array}{l}0.2702^{\star *} \\
(0.1163)\end{array}$ & $\begin{array}{l}0.0065^{\star *} \\
(0.0028)\end{array}$ & $\begin{array}{c}0.2317 \\
(0.1678)\end{array}$ & --- & --- & $\begin{array}{c}-0.7365^{* *} \\
(0.3711)\end{array}$ & $\begin{array}{l}0.148 \\
(368)\end{array}$ \\
\hline & $\begin{array}{c}0.2463 \\
(0.1307)\end{array}$ & $\begin{array}{c}0.0058 \\
(0.0031)\end{array}$ & $\begin{array}{c}0.0781 \\
(0.1898)\end{array}$ & $\begin{array}{l}-0.3444 \\
(0.3669)\end{array}$ & $\begin{array}{c}0.2592 \\
(0.3876)\end{array}$ & $\begin{array}{l}-0.1421 \\
(0.6295)\end{array}$ & $\begin{array}{l}0.169 \\
(368)\end{array}$ \\
\hline \multirow[t]{2}{*}{$\begin{array}{l}\text { Monitoring } \\
\text { Rights }\end{array}$} & $\begin{array}{l}0.5176^{\star \star} \\
(0.2428)\end{array}$ & $\begin{array}{c}0.0136^{\star *} \\
(0.006)\end{array}$ & $\begin{array}{c}0.274 \\
(0.2959)\end{array}$ & --- & --- & $\begin{array}{l}-2.372^{* *} \\
(0.7614)\end{array}$ & $\begin{array}{l}0.312 \\
(115)\end{array}$ \\
\hline & $\begin{array}{l}0.5726 \\
(0.311)\end{array}$ & $\begin{array}{l}0.0141^{\star *} \\
(0.0066)\end{array}$ & $\begin{array}{l}0.0752 \\
(0.336)\end{array}$ & $\begin{array}{l}-0.2100 \\
(0.6867)\end{array}$ & $\begin{array}{c}0.5188 \\
(0.7957)\end{array}$ & $\begin{array}{c}-2.1225 \\
(1.3118)\end{array}$ & $\begin{array}{l}0.337 \\
(115)\end{array}$ \\
\hline \multirow[t]{2}{*}{$\begin{array}{l}\text { Termination } \\
\text { Rights }\end{array}$} & $\begin{array}{c}0.296^{\star *} \\
(0.0848)\end{array}$ & $\begin{array}{l}0.0085^{\star *} \\
(0.0025)\end{array}$ & $\begin{array}{l}0.1284 \\
(0.152)\end{array}$ & --- & --- & $\begin{array}{c}-1.6067^{* *} \\
(0.3346)\end{array}$ & $\begin{array}{l}0.162 \\
(253)\end{array}$ \\
\hline & $\begin{array}{l}0.1934^{\star \star} \\
(0.0942)\end{array}$ & $\begin{array}{l}0.0061^{* *} \\
(0.0027)\end{array}$ & $\begin{array}{c}0.0703 \\
(0.1827)\end{array}$ & $\begin{array}{c}-0.9405^{\star *} \\
(0.3611)\end{array}$ & $\begin{array}{c}-0.3960 \\
(0.3583)\end{array}$ & $\begin{array}{l}-0.3298 \\
(0.5622)\end{array}$ & $\begin{array}{l}0.19 \\
(253)\end{array}$ \\
\hline $\begin{array}{l}\text { Total } \\
\text { Number of } \\
\text { Clauses }\end{array}$ & $\begin{array}{l}0.2839^{\star *} \\
(0.0626)\end{array}$ & $\begin{array}{l}0.0076^{\star *} \\
(0.0017)\end{array}$ & $\begin{array}{c}0.1713 \\
(0.1)\end{array}$ & --- & --- & $\begin{array}{l}-1.136^{\star *} \\
(0.2194)\end{array}$ & $\begin{array}{l}0.154 \\
(736)\end{array}$ \\
\hline Used $^{\text {a }}$ & $\begin{array}{l}0.2178^{* *} \\
(0.0679)\end{array}$ & $\begin{array}{l}0.0061^{* *} \\
(0.0018)\end{array}$ & $\begin{array}{l}0.0765 \\
(0.116)\end{array}$ & $\begin{array}{l}-0.612^{* *} \\
(0.2332)\end{array}$ & $\begin{array}{l}-0.1049 \\
(0.237)\end{array}$ & $\begin{array}{c}-0.2291 \\
(0.3704)\end{array}$ & $\begin{array}{l}0.173 \\
(736)\end{array}$ \\
\hline
\end{tabular}

Notes: ${ }^{\text {a }}$ Completion, monitoring and termination. ${ }^{*}$ Significant at $5 \%$ level; ${ }^{* *}$ Significant at $1 \%$ level. 
Table 5. Variation of Individual Rights

(WLS Regressions for probability that right assigned to manufacturer)

\begin{tabular}{|c|c|c|c|c|c|c|}
\hline \multirow{2}{*}{$\begin{array}{l}\text { Dependent } \\
\text { Variables }\end{array}$} & \multicolumn{4}{|c|}{ Independent Variables } & \multirow{2}{*}{ Intercept } & \multirow[b]{2}{*}{$R S q .(N)$} \\
\hline & $\begin{array}{l}\text { Average } \\
\text { Car Price }\end{array}$ & $\begin{array}{l}\text { Dealers in } \\
\text { Network }\end{array}$ & $\begin{array}{l}\text { Log Age of } \\
\text { Network }\end{array}$ & Asia & & \\
\hline \multicolumn{7}{|c|}{ 1. Manufacturer ex post completion rights: } \\
\hline $\begin{array}{l}\text { Compulsory Sales } \\
\text { Training }\end{array}$ & $\begin{array}{c}0.0147 \\
(0.0333)\end{array}$ & $\begin{array}{l}-0.0002 \\
(0.0015)\end{array}$ & $\begin{array}{c}0.0434 \\
(0.1073)\end{array}$ & $\begin{array}{c}-0.7663^{\star \star} \\
(0.2480)\end{array}$ & $\begin{array}{l}0.7490^{\star} \\
(0.4454)\end{array}$ & $\begin{array}{c}0.6652 \\
(23)\end{array}$ \\
\hline $\begin{array}{l}\text { Minimum Trial } \\
\text { Vehicles }\end{array}$ & $\begin{array}{c}0.0433 \\
(0.0287)\end{array}$ & $\begin{array}{c}0.0011 \\
(0.0013)\end{array}$ & $\begin{array}{c}0.014 \\
(0.0544)\end{array}$ & $\begin{array}{c}-0.6889^{* *} \\
(0.1765)\end{array}$ & $\begin{array}{c}0.4898 \\
(0.3307)\end{array}$ & $\begin{array}{l}0.9070 \\
(23)\end{array}$ \\
\hline Minimum Capital & $\begin{array}{l}0.0706^{* *} \\
(0.0204)\end{array}$ & $\begin{array}{l}0.0025^{\star *} \\
(0.0008)\end{array}$ & $\begin{array}{l}0.0799^{\star} \\
(0.0429)\end{array}$ & $\begin{array}{l}-0.4824^{\star *} \\
(0.1325)\end{array}$ & $\begin{array}{c}0.0271 \\
(0.2443)\end{array}$ & $\begin{array}{c}0.9662 \\
(23)\end{array}$ \\
\hline $\begin{array}{l}\text { Limit Sales Out of } \\
\text { Territory }\end{array}$ & $\begin{array}{l}0.0706^{\star *} \\
(0.0204)\end{array}$ & $\begin{array}{l}0.0025^{\star *} \\
(0.0008)\end{array}$ & $\begin{array}{l}0.0799^{\star} \\
(0.0429)\end{array}$ & $\begin{array}{l}-0.4824^{* *} \\
(0.1325)\end{array}$ & $\begin{array}{c}0.0271 \\
(0.2443)\end{array}$ & $\begin{array}{c}0.9662 \\
(23)\end{array}$ \\
\hline \multicolumn{7}{|c|}{ 2. Monitoring Rights: } \\
\hline $\begin{array}{l}\text { Provision of } \\
\text { Accounting Data }\end{array}$ & $\begin{array}{c}0.0075 \\
(0.0169)\end{array}$ & $\begin{array}{c}0.0003 \\
(0.0006)\end{array}$ & $\begin{array}{c}0.0094 \\
(0.0496)\end{array}$ & $\begin{array}{c}-0.3174^{\star *} \\
(0.145)\end{array}$ & $\begin{array}{l}0.9006^{\star *} \\
(0.2163)\end{array}$ & $\begin{array}{l}0.3607 \\
(23)\end{array}$ \\
\hline Poll Clients & $\begin{array}{l}0.0442^{\star *} \\
(0.0219)\end{array}$ & $\begin{array}{l}0.0012^{*} \\
(0.0007)\end{array}$ & $\begin{array}{l}0.1251^{\star *} \\
(0.0608)\end{array}$ & $\begin{array}{l}-0.3151 \\
(0.1989)\end{array}$ & $\begin{array}{c}0.2122 \\
(0.3376)\end{array}$ & $\begin{array}{l}0.6897 \\
(23)\end{array}$ \\
\hline Audit Accounting & $\begin{array}{l}0.0706^{\star \star} \\
(0.0204)\end{array}$ & $\begin{array}{l}0.0025^{\star \star} \\
(0.0008)\end{array}$ & $\begin{array}{l}0.0799^{\star} \\
(0.0429)\end{array}$ & $\begin{array}{l}-0.4824^{\star *} \\
(0.1325)\end{array}$ & $\begin{array}{c}0.0271 \\
(0.2443)\end{array}$ & $\begin{array}{c}0.9662 \\
(23)\end{array}$ \\
\hline \multicolumn{7}{|c|}{ 3.Termination Rights: } \\
\hline $\begin{array}{l}\text { Change of } \\
\text { Management }\end{array}$ & $\begin{array}{l}0.0083 \\
(0.022)\end{array}$ & $\begin{array}{c}0.0002 \\
(0.0006)\end{array}$ & $\begin{array}{c}0.036 \\
(0.0482)\end{array}$ & $\begin{array}{l}-0.4341^{\star \star} \\
(0.1538)\end{array}$ & $\begin{array}{l}0.8241^{\star *} \\
(0.2393)\end{array}$ & $\begin{array}{c}0.5171 \\
(23)\end{array}$ \\
\hline Disagreement & $\begin{array}{c}0.0213 \\
(0.0158)\end{array}$ & $\begin{array}{c}0.0008 \\
(0.0006)\end{array}$ & $\begin{array}{l}0.0089 \\
(0.032)\end{array}$ & $\begin{array}{l}-0.8648^{\star *} \\
(0.0929)\end{array}$ & $\begin{array}{l}0.7452^{\star *} \\
(0.1773)\end{array}$ & $\begin{array}{l}0.9805 \\
(23)\end{array}$ \\
\hline Change of Location & $\begin{array}{c}0.0479 \\
(0.0299)\end{array}$ & $\begin{array}{c}0.0015 \\
(0.0013)\end{array}$ & $\begin{array}{c}0.0911 \\
(0.0784)\end{array}$ & $\begin{array}{c}-0.5022^{* *} \\
(0.2264)\end{array}$ & $\begin{array}{c}0.2469 \\
(0.3711)\end{array}$ & $\begin{array}{c}0.8790 \\
(23)\end{array}$ \\
\hline Liquidation & $\begin{array}{c}0.0351 \\
(0.0279)\end{array}$ & $\begin{array}{l}0.0016^{*} \\
(0.0009)\end{array}$ & $\begin{array}{c}0.0052 \\
(0.0408)\end{array}$ & $\begin{array}{c}-0.7496^{\star *} \\
(0.1295)\end{array}$ & $\begin{array}{l}0.5569^{* *} \\
(0.2446)\end{array}$ & $\begin{array}{c}0.9639 \\
(23)\end{array}$ \\
\hline Court Verdict & $\begin{array}{l}0.1304^{* *} \\
(0.0169)\end{array}$ & $\begin{array}{l}0.0047^{* *} \\
(0.0009)\end{array}$ & $\begin{array}{c}0.0431 \\
(0.0557)\end{array}$ & $\begin{array}{l}-0.1091 \\
(0.0847)\end{array}$ & $\begin{array}{c}-0.5627^{\star *} \\
(0.1513)\end{array}$ & $\begin{array}{c}0.9104 \\
(23)\end{array}$ \\
\hline False Information & $\begin{array}{l}0.1397^{\star *} \\
(0.0157)\end{array}$ & $\begin{array}{c}0.0045^{\star \star} \\
(0.001)\end{array}$ & $\begin{array}{c}-0.0304 \\
(0.0471)\end{array}$ & $\begin{array}{l}-0.0828 \\
(0.0757)\end{array}$ & $\begin{array}{c}-0.4681^{\star *} \\
(0.1462)\end{array}$ & $\begin{array}{c}0.9000 \\
(23)\end{array}$ \\
\hline Loss of Control & $\begin{array}{c}0.0025 \\
(0.0143)\end{array}$ & $\begin{array}{c}0.0012 \\
(0.0008)\end{array}$ & $\begin{array}{l}-0.0142 \\
(0.0476)\end{array}$ & $\begin{array}{l}-0.0289 \\
(0.0751)\end{array}$ & $\begin{array}{c}-0.0313 \\
(0.186)\end{array}$ & $\begin{array}{c}0.1537 \\
(23)\end{array}$ \\
\hline Dealership Closed & $\begin{array}{l}0.0732^{\star *} \\
(0.0263)\end{array}$ & $\begin{array}{c}0.0011 \\
(0.0008)\end{array}$ & $\begin{array}{c}-0.0376 \\
(0.0358)\end{array}$ & $\begin{array}{c}-0.0162 \\
(0.0536)\end{array}$ & $\begin{array}{c}-0.157 \\
(0.1153)\end{array}$ & $\begin{array}{c}0.3159 \\
(23)\end{array}$ \\
\hline
\end{tabular}

Notes: Estimated by Weighted Least Squares * Significant at 5\% level. ${ }^{* *}$ Significant at $1 \%$ level. 
Table 6. Intensity of Monetary Incentives

\begin{tabular}{|c|c|c|c|c|c|c|c|}
\hline \multirow[b]{2}{*}{$\begin{array}{c}\text { Dependent } \\
\text { variables }\end{array}$} & \multicolumn{5}{|c|}{ Independent variables } & \multirow[b]{2}{*}{ Intercept } & \multirow[b]{2}{*}{$\begin{array}{c}\text { Pseudo } R \\
\text { Sq. (N) }\end{array}$} \\
\hline & $\begin{array}{l}\text { Average } \\
\text { Car Price }\end{array}$ & $\begin{array}{c}\text { Dealers } \\
\text { In } \\
\text { Network }\end{array}$ & $\begin{array}{c}\log A g e \\
\text { of } \\
\text { Network }\end{array}$ & Asia & Europe & & \\
\hline \multirow[t]{2}{*}{$\begin{array}{l}\text { Use of } \\
\text { Discounts }\end{array}$} & $\begin{array}{c}0.241 \\
(0.408)\end{array}$ & $\begin{array}{c}0.068 \\
(0.045)\end{array}$ & $\begin{array}{l}2.539^{*} \\
(1.493)\end{array}$ & & & & $\begin{array}{c}0.598 \\
(23)\end{array}$ \\
\hline & $\begin{array}{c}-0.428 \\
(1.026)\end{array}$ & $\begin{array}{l}0.078 \\
(0.05)\end{array}$ & $\begin{array}{c}2.916 \\
(2.571)\end{array}$ & $\begin{array}{c}-6.46 \\
(7.411)\end{array}$ & $\begin{array}{l}-0.328 \\
(3.779)\end{array}$ & & $\begin{array}{c}0.689 \\
(23)\end{array}$ \\
\hline \multirow{2}{*}{$\begin{array}{l}\text { Level of } \\
\text { Sales } \\
\text { Discounts }\end{array}$} & $\begin{array}{l}0.199^{* *} \\
(0.092)\end{array}$ & $\begin{array}{c}0.001 \\
(0.004)\end{array}$ & $\begin{array}{c}0.185 \\
(0.241)\end{array}$ & & & $\begin{array}{c}0.131 \\
(0.533)\end{array}$ & $\begin{array}{c}0.137 \\
(23)\end{array}$ \\
\hline & $\begin{array}{l}0.116 \\
(0.11)\end{array}$ & $\begin{array}{l}-0.002 \\
(0.004)\end{array}$ & $\begin{array}{c}0.356 \\
(0.291)\end{array}$ & $\begin{array}{l}-0.549 \\
(0.507)\end{array}$ & $\begin{array}{l}-0.616 \\
(0.463)\end{array}$ & $\begin{array}{l}0.718 \\
(0.83)\end{array}$ & $\begin{array}{c}0.169 \\
(23)\end{array}$ \\
\hline \multirow{2}{*}{$\begin{array}{l}\text { Range of } \\
\text { Sales } \\
\text { Discounts }\end{array}$} & $\begin{array}{l}0.095 \\
(0.11)\end{array}$ & $\begin{array}{l}-0.004 \\
(0.004)\end{array}$ & $\begin{array}{c}0.67^{\star *} \\
(0.291)\end{array}$ & & & $\begin{array}{l}-0.089 \\
(0.646)\end{array}$ & $\begin{array}{l}0.14 \\
(23)\end{array}$ \\
\hline & $\begin{array}{c}0.03 \\
(0.135)\end{array}$ & $\begin{array}{l}-0.006 \\
(0.005)\end{array}$ & $\begin{array}{l}0.685^{\star} \\
(0.362)\end{array}$ & $\begin{array}{l}-0.542 \\
(0.624)\end{array}$ & $\begin{array}{l}-0.286 \\
(0.57)\end{array}$ & $\begin{array}{c}0.611 \\
(1.022)\end{array}$ & $\begin{array}{c}0.152 \\
(23)\end{array}$ \\
\hline \multirow{2}{*}{$\begin{array}{l}\text { Level of } \\
\text { Service } \\
\text { Discounts }\end{array}$} & $\begin{array}{c}0.008 \\
(0.066)\end{array}$ & $\begin{array}{c}0.002 \\
(0.002)\end{array}$ & $\begin{array}{l}0.372^{* *} \\
(0.177)\end{array}$ & & & $\begin{array}{l}-1.177 \\
(0.504)\end{array}$ & $\begin{array}{c}0.427 \\
(23)\end{array}$ \\
\hline & $\begin{array}{c}0.011 \\
(0.075)\end{array}$ & $\begin{array}{c}0.003 \\
(0.003)\end{array}$ & $\begin{array}{c}0.16 \\
(0.202)\end{array}$ & $\begin{array}{l}-0.131 \\
(0.347)\end{array}$ & $\begin{array}{c}0.307 \\
(0.294)\end{array}$ & $\begin{array}{l}-0.788 \\
(0.587)\end{array}$ & $\begin{array}{c}0.503 \\
(23)\end{array}$ \\
\hline \multirow{2}{*}{$\begin{array}{l}\text { Range of } \\
\text { Service } \\
\text { Discounts }\end{array}$} & $\begin{array}{l}-0.022 \\
(0.074)\end{array}$ & $\begin{array}{c}0.001 \\
(0.002)\end{array}$ & $\begin{array}{l}0.482^{* *} \\
(0.188)\end{array}$ & & & $\begin{array}{c}-1.304^{\star *} \\
(0.541)\end{array}$ & $\begin{array}{c}0.451 \\
(23)\end{array}$ \\
\hline & $\begin{array}{r}-0.067 \\
(0.08)\end{array}$ & $\begin{array}{c}0.000 \\
(0.003)\end{array}$ & $\begin{array}{c}0.357 \\
(0.216)\end{array}$ & $\begin{array}{c}-0.517 \\
(0.36)\end{array}$ & $\begin{array}{c}0.003 \\
(0.298)\end{array}$ & $\begin{array}{c}-0.545 \\
(0.594)\end{array}$ & $\begin{array}{c}0.539 \\
(23)\end{array}$ \\
\hline
\end{tabular}


Table 7. Dealership Network Profitability

\begin{tabular}{|c|c|c|c|c|c|c|c|c|c|}
\hline & $\begin{array}{c}\text { Dummy } \\
1993\end{array}$ & $\begin{array}{c}\text { Dummy } \\
1995\end{array}$ & $\begin{array}{l}\text { Average } \\
\text { Car Price }\end{array}$ & $\begin{array}{c}\text { Dealers } \\
\text { In } \\
\text { Network }\end{array}$ & $\begin{array}{l}\text { Log Age } \\
\text { Network }\end{array}$ & Asia & Europe & Intercept & $\begin{array}{c}R S q . \\
(N)\end{array}$ \\
\hline \multirow{2}{*}{$\begin{array}{l}\text { Return } \\
\text { on Sales, } \\
1993- \\
1995\end{array}$} & $\begin{array}{c}-0.3129 * * \\
(0.0198)\end{array}$ & $\begin{array}{l}0.4343^{* *} \\
(0.0201)\end{array}$ & $\begin{array}{c}0.032^{\star *} \\
(0.0104)\end{array}$ & $\begin{array}{c}0.0002 \\
(0.0002)\end{array}$ & $\begin{array}{l}-0.0233 \\
(0.0162)\end{array}$ & & & $\begin{array}{l}0.6142^{* *} \\
(0.0464)\end{array}$ & $\begin{array}{c}0.9662 \\
(50)\end{array}$ \\
\hline & $\begin{array}{c}-0.3129^{* \star} \\
(0.02)\end{array}$ & $\begin{array}{l}0.4343^{* *} \\
(0.0203)\end{array}$ & $\begin{array}{l}0.0288^{* *} \\
(0.0109)\end{array}$ & $\begin{array}{c}0.0002 \\
(0.0002)\end{array}$ & $\begin{array}{l}-0.0262 \\
(0.0199)\end{array}$ & $\begin{array}{l}-0.0272 \\
(0.0302)\end{array}$ & $\begin{array}{c}-0.007 \\
(0.0304)\end{array}$ & $\begin{array}{l}0.6501^{* *} \\
(0.0577)\end{array}$ & $\begin{array}{c}0.9655 \\
(50)\end{array}$ \\
\hline
\end{tabular}

Notes: Three year panel for the available returns on sales; * significant at $10 \%$ level; ** significant at $5 \%$; standard errors within parentheses. 
Table 8. Complementarities (I): Unconditional Correlations

\begin{tabular}{|c|c|c|c|c|c|c|c|c|}
\hline & $\begin{array}{c}\text { Completion } \\
\text { Rights }\end{array}$ & $\begin{array}{c}\text { Monitoring } \\
\text { Rights }\end{array}$ & $\begin{array}{l}\text { Termina- } \\
\text { tion Rights }\end{array}$ & $\begin{array}{l}\text { Level } \\
\text { Sales Dis- } \\
\text { count }\end{array}$ & $\begin{array}{c}\text { Range } \\
\text { Sales Dis- } \\
\text { count }\end{array}$ & $\begin{array}{l}\text { Level } \\
\text { Service } \\
\text { Discount }\end{array}$ & $\begin{array}{l}\text { Range } \\
\text { Service } \\
\text { Discount }\end{array}$ & $\begin{array}{l}\text { Quasi- } \\
\text { Rents ** }\end{array}$ \\
\hline Completion Rights & 1 & & & & & & & \\
\hline Monitoring Rights & $0.8422^{*}$ & 1 & & & & & & \\
\hline Termination Rights & $0.9178^{*}$ & $0.8234^{*}$ & 1 & & & & & \\
\hline Level Sales Discount & 0.2246 & 0.3838 & 0.2858 & 1 & & & & \\
\hline Range Sales Discount & 0.3177 & $0.6228^{*}$ & 0.3795 & $0.6336^{*}$ & 1 & & & \\
\hline Level Service Discount & $0.6399^{*}$ & $0.6351^{*}$ & $0.4825^{\star}$ & 0.0567 & 0.1602 & 1 & & \\
\hline Range Service Discount & $0.5822^{*}$ & $0.5937^{*}$ & $0.5272^{*}$ & 0.0528 & 0.309 & $0.7906^{*}$ & 1 & \\
\hline Quasi-Rents ** & -0.0339 & 0.2911 & -0.0972 & 0.1076 & $0.5187^{*}$ & 0.0673 & -0.0511 & 1 \\
\hline
\end{tabular}

Notes: $\left({ }^{*}\right)$ Correlation statistically significant at $5 \%$ level. $\left({ }^{* *}\right)$ As proxied by Return on Sales. This row is based only on the 16 networks for which profitability data was available. 
Table 9. Complementarities (II): Conditional Correlations

\begin{tabular}{|c|c|c|c|c|c|c|c|c|}
\hline & $\begin{array}{c}\text { Comple- } \\
\text { tion } \\
\text { Rights }\end{array}$ & $\begin{array}{l}\text { Monitor- } \\
\text { ing Rights }\end{array}$ & $\begin{array}{c}\text { Termina- } \\
\text { tion } \\
\text { Rights }\end{array}$ & $\begin{array}{c}\text { Level } \\
\text { Sales Dis } \\
\text { count }\end{array}$ & $\begin{array}{c}\text { Range } \\
\text { - Sales Dis- } \\
\text { count }\end{array}$ & $\begin{array}{c}\text { Level } \\
\text { Service } \\
\text { Discount }\end{array}$ & $\begin{array}{l}\text { Range } \\
\text { Service } \\
\text { Discount }\end{array}$ & $\begin{array}{l}\text { Quasi- } \\
\text { Rents ** }\end{array}$ \\
\hline Completion Rights & 1 & & & & & & & \\
\hline Monitoring Rights & 0.1002 & 1 & & & & & & \\
\hline Termination Rights & $0.5329^{*}$ & 0.0599 & 1 & & & & & \\
\hline Level Sales Discount & -0.37 & 0.1536 & -0.2492 & 1 & & & & \\
\hline Range Sales Discount & -0.304 & $0.6244^{*}$ & 0.0189 & $0.6511^{*}$ & 1 & & & \\
\hline Level Service Discount & 0.3015 & 0.3598 & -0.1185 & 0.0838 & -0.0031 & 1 & & \\
\hline Range Service Discount & 0.1245 & 0.3056 & -0.0359 & 0.0868 & 0.1319 & $0.8221^{*}$ & 1 & \\
\hline Quasi-Rents ** & -0.2417 & 0.3981 & -0.3335 & -0.0396 & 0.3826 & -0.0652 & -0.1655 & 1 \\
\hline
\end{tabular}

Notes: The correlations are of generalized residuals of Tobit models for Sales and Service Discounts, constructed as suggested by Gourieroux, Monfort, Renault and Trognon (1987), and of the Panel Regressions for the Return on Sales. ( ${ }^{*}$ ) Correlation statistically significant at 5\% level. $\left(^{* *}\right)$ As proxied by Return on Sales. This row is based only on the 16 networks for which profitability data was available. 


\section{APPENDIX: DATA SOURCES}

The analysis included the contracts of Alfa Romeo, Audi, BMW, Chrysler, Citröen, Daewoo, Fiat, Ford, Honda, Hyundai, Jaguar, Lancia, Mazda, Mercedes, Mitsubishi, Nissan, Opel, Peugeot, Renault, Rover, Seat, Skoda, Suzuki, Toyota, Volkswagen y Volvo. These manufacturers produced in $199499.3 \%$ of the total number of automobiles sold in Spain. (Ministerio de Justicia e Interior, 1995).We complemented these contracts with 48 in-depth interviews with experts in the sector. Among these experts were the general secretaries of the trade group of manufacturers and of dealers, ANFAC and FACONAUTO respectively; 23 franchisees of different brands; and 23 managers of the distribution networks of the manufacturers. 
Table A1: Descriptive Statistics of Independent Variables

\begin{tabular}{lrrrrr}
\hline & Obs & Mean & $\begin{array}{c}\text { Std. } \\
\text { Dev. }\end{array}$ & Min & Max \\
\hline Price & 23 & 3.174 & 1.935 & 1.648 & 10.587 \\
Dealers & 23 & 109.348 & 65.417 & 17 & 231 \\
LnAge & 23 & 2.697 & 0.885 & 0.693 & 4.357 \\
Asia & 23 & 0.348 & 0.487 & 0 & 1 \\
Europe & 23 & 0.478 & 0.511 & 0 & 1 \\
\hline
\end{tabular}

Unconditional Correlation Table

\begin{tabular}{lrrrrr}
\hline & \multicolumn{1}{c}{ Price } & Dealers & LnAge & Asia & Europe \\
\hline Price & 1 & & & & \\
Dealers & -0.4388 & 1 & & & \\
LnAge & 0.0455 & 0.636 & 1 & & \\
Asia & -0.2528 & -0.4135 & -0.6319 & 1 & \\
Europe & -0.0333 & 0.324 & 0.6332 & -0.6992 & 1 \\
\hline
\end{tabular}


Table A2: Return on Sales (ROS)

\begin{tabular}{crrrrr}
\hline Variable & \multicolumn{1}{c}{ Obs } & \multicolumn{1}{c}{ Mean } & Std. Dev. & \multicolumn{1}{l}{ Min } & \multicolumn{1}{c}{ Max } \\
\hline ROS 93 & 17 & 0.3518 & 0.0436 & 0.24 & 0.41 \\
ROS 94 & 17 & 0.6647 & 0.0646 & 0.5 & 0.77 \\
ROS 95 & 16 & 1.1 & 0.0770 & 0.93 & 1.23 \\
\hline
\end{tabular}

\begin{tabular}{lrrr}
\hline & ROS 93 & ROS 94 & ROS 95 \\
\hline ROS 93 & 1 & & \\
ROS 94 & 0.8327 & 1 & \\
ROS 95 & 0.7809 & 0.7371 & 1 \\
\hline
\end{tabular}

